\title{
Fine Needle Diathermy for Corneal Neovascularization: Initial Results
}

\author{
Osman Şalkacı,, Ümit Çallı, Baran Kandemir, ${ }^{1}$ Taha Ayyıldız
}

\footnotetext{
'Department of Ophthalmology, Kartal Dr. Lütfi Kırdar Training and Research Hospital, İstanbul, Turkey

${ }^{2}$ Department of Ophthalmology, Haydarpaşa Numune Training and Research Hospital, İstanbul, Turkey

Submitted: 14.12.2015 Accepted: 31.12 .2015

Correspondence: Osman Şalkacı, Kartal Dr. Lütfi Kırdar Eğitim ve Araştırma Hastanesi, Göz

Hastalıkları Kliniği, Kartal, Turkey

E-mail: salkacigoz@mynet.com

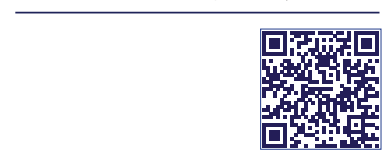

Keywords: Corneal neovascularization; fine needle diathermy; occlusion.
}

\begin{abstract}
Objective: The present study is a report of first results of fine needle diathermy (FND) procedure, the method of treatment preferred in our clinic for patients with corneal neovascularization.
\end{abstract}

Methods: FND was performed on 34 eyes with corneal neovascularization in 34 patients. Anterior segment color photos were taken of all patients before and after the procedure. Visual acuity and vascularization size and depth before and after procedure were compared. Number of procedures and complications were noted.

Results: Causes of vascularization were lipid keratopathy with unknown primary pathology in 12 patients, herpetic keratitis in 9, bacterial keratitis in 6, corneal graft rejection in 3 , fungal keratitis in 2, alkaline burn in 2, and trauma in I patient. All vessels were successfully occluded in 15 patients. In 7 patients, $75 \%$ of treated vessels were occluded, and $50 \%$ of treated vessels were occluded in 5 patients. FND was performed twice on 12 patients and 3 times on 4 patients. In some cases, additional procedures were successful, and in others it was determined to be insufficient.

Conclusion: FND is a safe and effective treatment for corneal neovascularization in some patients; however, in some cases, the procedure is only partially effective.

\section{INTRODUCTION}

In order to maintain corneal transparency and optimal visual acuity, the cornea must remain avascular. ${ }^{[1]}$ Avascularity also ensures that the cornea retains its immune privilege. ${ }^{[2]}$ Corneal neovascularization is a threat can develop as a response to infection, hypoxia, trauma, limbal stem cell deficiency, or as a component of corneal disease or the healing process. ${ }^{[3,4]}$ Corneal vessels aid in the transport of materials necessary for immune cells, regeneration of the cornea, delivery of antibiotics to an infected area, and the removal of metabolites. When the healing process is complete, however, blood flow in corneal vessels may continue and impair corneal transparency and ability to limit local immune and inflammatory responses, constituting a risk factor for rejection and corneal graft inadequacy in cornea transplant patients. ${ }^{[5,6]}$ As has been demonstrated in many studies, treatment of neovascularization before corneal transplantation prolongs graft life. ${ }^{[7]}$ Many agents and methods such as steroids, radiation, cystine, cryotherapy, and dextran have been used to occlude corneal vessels. ${ }^{[8-11]}$ Ophthalmologists have also used argon laser ${ }^{[12-17]}$ and 577-nm yellow dye laser ${ }^{[18,19]}$ to occlude corneal vessels and have reported successful outcomes. The present study is a report of experience with fine needle diathermy (FND), the method used in our clinic to treat patients with corneal neovascularization.

\section{PATIENTS AND METHODS}

FND was performed on 34 patients with corneal neovascularization. All patients provided written, 
informed consent before enrollment in the study. The principles of the Second Declaration of Helsinki were observed, and approval of the Kartal Dr. Lütfi Kırdar Training and Research Hospital Ethics Committee was obtained. Etiological factors, extent, and depth of vascularization were noted. Before and after the procedure, color photos of anterior segment were taken. Pre- and postprocedural visual acuity and degree of vascularization were compared, the number of procedures, and related complications were recorded.

For all statistical analyses, SPSS software (version 17.0; SPSS Inc., Chicago, IL, USA) was used. Postprocedural changes in visual acuity relative to preprocedural measurements were analyzed using paired sample t-test.

\section{Fine needle Diathermy Technique}

Topical anesthesia was achieved with eye drops containing proparacaine hydrochloride ophthalmic solution. For FND procedure, a 10-0 nylon suture needle was inserted 0.5 to $1 \mathrm{~mm}$ from limbus in order to avoid traumatizing stem cell, and passed parallel to and at same depth as the blood vessel(s) to be occluded. Probe of unipolar diathermy unit at lowest setting (i.e., coagulation mode) was applied to the needle for I to 2 seconds until corneal stroma whitened. The same technique was used on all areas of vascularization.

After the procedure, ofloxacin and loteprednol eye drops were applied to the affected eyes of the patients 4 times a day for I week. Patients were also started on prophylactic topical asiviral ophthalmic ointment treatment if condition was sequela of herpes simplex keratitis. Effectiveness of FND and related complications were evaluated on postprocedural first day, at first and second week, and at first and third month (Figure I).

\section{RESULTS}

The study population consisted of 24 male and 10 female patients, with an overall mean age of $43.3 \pm 13.3$ years (range: 5-68 years). Etiologies of vascularization included lipid keratopathy with unknown primary pathology, herpes keratitis $(n=9)$, bacterial keratitis $(n=6)$, graft rejection $(n=3)$, fungal keratitis $(n=2)$, alkaline burn wound $(n=2)$, and a traumatic event $(n=I)$. Vascularization involved 4 quadrants $(n=5), 3$ quadrants $(n=3), 2$ quadrants $(n=\mid 2)$, and $\mid(n=\mid 4)$ quadrant in respective number of patients. Superficial $(n=19)$, deep $(n=8)$, and both deep and superficial $(n=6)$ vascularization was detected. In 15 patients, all vessels treated were occluded, while $75 \%$ and $50 \%$ of vascularized vessels could be occluded in 7 and 5 patients, respectively. In 7 patients, previously occluded vessels recanalized during follow-up period. Patients underwent FND procedure for a second time $(n=12)$ and a third $(n=4)$ time. Subsequent response in some of these patients was not satisfactory. Two patients underwent cultivated limbal stem cell transplantation following FND procedure. Mean pre- and postprocedural visual acuity of the patients were $2 \pm 0.85$ $\log M A R$ and $1.34 \pm 0.8 \mathrm{I} \log M A R$, respectively, with a statistically significant difference between them (paired sample t-test; $p=0.037$ ). Intrastromal bleeding was observed, but complication resolved without sequelae. In 2 patients, fluid leakage from anterior chamber was seen and repaired with a single suture in I patient and 2 sutures in the other patient.

\section{DISCUSSION}

Numerous medical agents have been used in the treatment of corneal neovascularization. ${ }^{[20]}$ Corticosteroids have been accepted as standard treatment for active corneal neovascularization. ${ }^{[2]}$ Even though they were found to be particularly effective in corneal neovascularization associated with cornea transplants, ${ }^{[21]}$ they are not effective in cases of stable corneal neovascularization. ${ }^{[21]}$ Because long-term steroid use has been associated with various complications (e.g., cataract, glaucoma, opportunistic infection), alternative treatments have been researched. Nonsteroidal anti-inflammatory drugs (NSAIDs) have also been used in the treatment of corneal neovascularization; ${ }^{[22,23]}$ however, varying effectiveness and occasionally serious side effects such as corneal ulceration have limited clinical use. ${ }^{[24]}$

Thermal coagulation and occlusion of vessels can also be done using laser beams. ${ }^{[25-33]}$ Cherry and Garner used ${ }^{[28]}$ corneal argon laser photocoagulation (CALP) on 4 patients for treatment of chemical burn $(n=2)$ and herpetic keratitis $(n=2)$, and reported 2 failures, I partial success, and I complete success. In another study, Marsh et al. followed 4I patients who had undergone CALP for lipid keratopathy, and after 9 months they found decrease in corneal opacity in 28 patients, and increase or stabilization in visual acuity in 33. ${ }^{[29,30]}$ Nirankari and Baer reported successful 

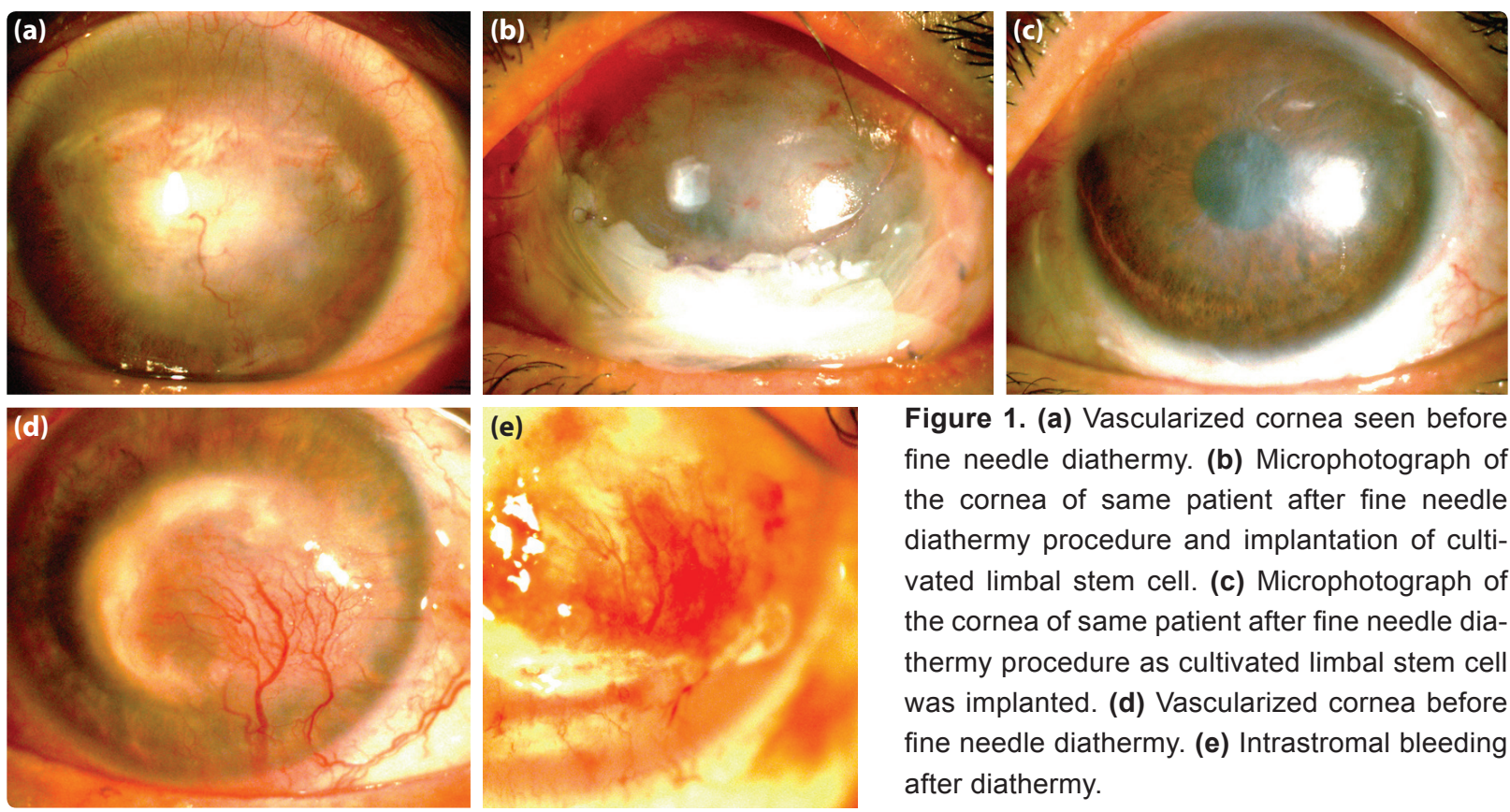

Figure 1. (a) Vascularized cornea seen before fine needle diathermy. (b) Microphotograph of the cornea of same patient after fine needle diathermy procedure and implantation of cultivated limbal stem cell. (c) Microphotograph of the cornea of same patient after fine needle diathermy procedure as cultivated limbal stem cell was implanted. (d) Vascularized cornea before fine needle diathermy. (e) Intrastromal bleeding after diathermy. outcomes in patients who had undergone CALP procedure for deep corneal neovascularization. ${ }^{[3]]}$ Baer et al. ${ }^{[26]}$ used $577 \mathrm{~nm}$ yellow dye laser and reported reversal of graft rejection in 25 eyes of 23 patients and $68 \%$ decrease in corneal neovascularization. The authors did not, however, find CALP procedure effective in cases with diffuse corneal neovascularization. Due to complications such as iris atrophy and pupillary ectasia, as well as risk of accidental photocoagulation of fovea, CALP has limited use in clinical practice. ${ }^{[34]}$

FND is a promising surgical procedure in the treatment of corneal neovascularization. ${ }^{[35]}$ In various investigations, the treatment has been reported to be an effective, safe method for the occlusion of target vessels. ${ }^{[36-38]}$ As indicated in the literature, FND can also reverse corneal rejection. ${ }^{[36,37]}$ Pillai et al. ${ }^{[36]}$ used FND on 4 patient groups (median follow-up period of 10.3 months). In Group I ( $n=4)$, high-risk patients had received FND therapy before keratoplasty, and the authors reported no instance of rejection during a minimum postoperative follow-up period of 9 months. In Group 2, they achieved 100\% vascular occlusion and stable scar formation in patients $(n=2)$ with progressive lipid keratopathy. In Group 3, regression of all neovascularization and reversal of rejection reaction were observed in 4 patients. The 4 patients of Group 4 had inflamed disciform scar and saw inflammation resolved with no recurrence. As a complication, they reported intrastromal bleeding in only 3 patients. In the present study, corneal neovascularization was successfully occluded or regressed after FND procedure, corneal transparency improved, and visual acuity increased. In some patients, success level was improved after additional FND procedures, while in other patients, the desired level of response couldn't be achieved even after 3 attempts. These findings suggest that FND can be combined with topical ranibizumab or bevacizumab treatment.

In a study, Stevenson et al. ${ }^{[35]}$ applied topical $1 \%$ ranibizumab on 9 eyes of 9 patients, and I\% bevacizumab on 20 eyes of 20 patients 4 times a day for 3 weeks. Corneal neovascularization decreased approximately $39.8 \%$, and $55.3 \%$ at $3^{\text {rd }}$ and $16^{\text {th }}$ weeks, respectively. Neovascularization decreased more slowly (approximately $27.9 \%$ and $45.5 \%$ at $6^{\text {th }}$ and $24^{\text {th }}$ weeks, respectively) in the bevacizumab group. No ocular or systemic complications were observed. This result was interpreted as an effective and reliable outcome. Koenig et al. ${ }^{[39]}$ reported $80 \%$ decrease in neovascularization with topical application of 5 daily doses of $0.5 \%$ ophthalmic bevacizumab solution on 30 patients. In another study, Kim et al. ${ }^{[40]}$ reported $70 \%$ decrease in corneal neovascularization with topical application of $1.25 \%$ bevacizumab ophthalmic solution twice a day. Diverse outcomes have been obtained with application of ophthalmic medication of various concentrations and dosage schedules. Uni- 
versally accepted and optimized concentration and application frequency have not yet been established.

In conclusion, even though FND has been found to be a safe and effective procedure in selected patients, it can be ineffective in other patients. It is the opinion of the authors that use of topical bevacizumab or ranibizumab may increase effectiveness of the procedure. Additional studies performed with larger number of patients are needed to shed further light on this issue.

\section{Conflict of interest}

None declared.

\section{REFERENCES}

1. Beebe DC. Maintaining transparency: a review of the developmental physiology and pathophysiology of two avascular tissues. Semin Cell Dev Biol 2008;19:125-33.

2. Niederkorn JY. Immune privilege and immune regulation in the eye. Adv Immunol 1990;48:191-226.

3. Doggart JH. Vascularization of the cornea. Br J Ophthalmol 1951;35:160-7.

4. Klintworth GK. Corneal Angiogenesis: A Comprehensive Critical Review. New York: Springer-Verlag; 1991:11-2.

5. Lindstrom RL. Advances in corneal transplantation. N Engl J Med 1986;315:1-2.

6. Alldredge OC, Krachmer JH. Clinical types of corneal transplant rejection. Their manifestations, frequency, preoperative correlates, and treatment. Arch Ophthalmol 1981;99:599-604.

7. Nirankari VS, Baer JC. Corneal argon laser photocoagulation for neovascularization in penetrating keratoplasty. Ophthalmology 1986;93:1304-9.

8. Alldredge OC, Krachmer JH. Clinical types of corneal transplant rejection. Their manifestations, frequency, preoperative correlates, and treatment. Arch Ophthalmol 1981;99:599-604.

9. Ainslie D, Snelling MD, Ellis RE. Treatment of corneal vascularisation by strontium 90 beta plaque. Clin Symp 1962;13:29.

10. Lavergne G, Colmant IA. Comparative study of the action of thiotepa and triamcinolone on corneal vascularization in rabbits. $\mathrm{Br} \mathrm{J} \mathrm{Oph}$ thalmol 1964;48:416-22.

11. Mayer W. Cryotherapy in corneal vascularization. Arch Ophthalmol 1967;77:637-41.

12. Reed JW, Fromer C, Klintworth GK. Induced corneal vascularization remission with argon laser therapy. Arch Ophthalmol 1975;93:10179.

13. Marsh RJ, Marshall J. Treatment of lipid keratopathy with the argon laser. Br J Ophthalmol 1982;66:127-35.

14. Marsh RJ. Lasering of lipid keratopathy. Trans Ophthalmol Soc U K 1982;102:154-6.

15. Cherry PM, Faulkner JD, Shaver RP, Wise JB, Witter SL. Argon laser treatment of corneal neovascularization. Ann Ophthalmol 1973;5:911-20.

16. Cherry PM, Garner A. Corneal neovascularization treated with argon laser. Br J Ophthalmol 1976;60:464-72.

17. Baer JC, Foster CS. Corneal laser photocoagulation for treatment of neovascularization. Efficacy of $577 \mathrm{~nm}$ yellow dye laser. Ophthalmology 1992;99:173-9.
18. L'Esperance FA Jr. Ophthalmic lasers; Photocoagulation, photoradiation and surgery. St. Louis: CV Mosby; 1983.

19. L'Esperance FA Jr. Clinical photocoagulation with the organic dye laser. A preliminary communication. Arch Ophthalmol 1985;103:1312-6.

20. Chang JH, Gabison EE, Kato T, Azar DT. Corneal neovascularization. Curr Opin Ophthalmol 2001;12:242-9.

21. Cursiefen C, Wenkel H, Martus P, Langenbucher A, Nguyen NX, Seitz B, et al. Impact of short-term versus long-term topical steroids on corneal neovascularization after non-high-risk keratoplasty. Graefes Arch Clin Exp Ophthalmol 2001;239:514-21.

22. Takahashi K, Saishin Y, Saishin Y, Mori K, Ando A, Yamamoto S, et al. Topical nepafenac inhibits ocular neovascularization. Invest Ophthalmol Vis Sci 2003;44:409-15.

23. Frucht J, Zauberman H. Topical indomethacin effect on neovascularisation of the cornea and on prostaglandin E2 levels. $\mathrm{Br} \mathrm{J}$ Ophthalmol 1984;68:656-9.

24. Guidera AC, Luchs JI, Udell IJ. Keratitis, ulceration, and perforation associated with topical nonsteroidal anti-inflammatory drugs. Ophthalmology 2001;108:936-44.

25. Nirankari VS. Laser photocoagulation for corneal stromal vascularization. Trans Am Ophthalmol Soc 1992;90:595-669.

26. Baer JC, Foster CS. Corneal laser photocoagulation for treatment of neovascularization. Efficacy of $577 \mathrm{~nm}$ yellow dye laser. Ophthalmology 1992;99:173-9.

27. Parsa CF, Temprano J, Wilson D, Green WR. Hemorrhage complicating YAG laser feeder vessel coagulation of cornea vascularization. Cornea 1994;13:264-8.

28. Cherry PM, Garner A. Corneal neovascularization treated with argon laser. Br J Ophthalmol 1976;60:464-72.

29. Marsh RJ, Marshall J. Treatment of lipid keratopathy with the argon laser. Br J Ophthalmol 1982;66:127-35.

30. Marsh RJ. Argon laser treatment of lipid keratopathy. Br J Ophthalmol 1988;72:900-4.

31. Nirankari VS, Baer JC. Corneal argon laser photocoagulation for neovascularization in penetrating keratoplasty. Ophthalmology 1986;93:1304-9.

32. Gerten G. Bevacizumab (avastin) and argon laser to treat neovascularization in corneal transplant surgery. Cornea 2008;27:1195-9.

33. Pai VH, Handary SV. Necrotizing scleritis following laser therapy for corneal vascularization. Ann Ophthalmol (Skokie) 2009;41:50-1.

34. Pillai CT, Dua HS, Hossain P. Fine needle diathermy occlusion of corneal vessels. Invest Ophthalmol Vis Sci 2000;41:2148-53.

35. Stevenson W, Cheng SF, Dastjerdi MH, Ferrari G, Dana R. Corneal neovascularization and the utility of topical VEGF inhibition: ranibizumab (Lucentis) vs bevacizumab (Avastin). Ocul Surf 2012;10:6783.

36. Pillai CT, Dua HS, Hossain P. Fine needle diathermy occlusion of corneal vessels. Invest Ophthalmol Vis Sci 2000;41:2148-53.

37. Wertheim MS, Cook SD, Knox-Cartwright NE, Van DL, Tole DM. Electrolysis-needle cauterization of corneal vessels in patients with lipid keratopathy. Cornea 2007;26:230-1.

38. Thatte S. Fine needle diathermy - a choice for managing corneal vascularization. Nepal J Ophthalmol 2011;3:23-6.

39. Koenig Y, Bock F, Horn F, Kruse F, Straub K, Cursiefen C. Short- and long-term safety profile and efficacy of topical bevacizumab (Avastin) eye drops against corneal neovascularization. Graefes Arch Clin Exp Ophthalmol 2009;247:1375-82.

40. Kim SW, Ha BJ, Kim EK, Tchah H, Kim TI. The effect of topical bevacizumab on corneal neovascularization. Ophthalmology 2008;115:33-8. 


\section{Korneal Neovaskülarizasyonlarda İnce İğne Diatermi: İlk Sonuçlarımız}

Amaç: Bu çalışmada kliniğimizde korneal vaskülarizasyonu bulunan hastalarda tercih ettiğimiz ve uyguladığımız ince iğne diatermi (iiD) yönteminde ilk sonuçlarımızı bildirmeyi amaçladık.

Gereç ve Yöntem: Otuz dört hastanın korneal neovaskülarizasyonu olan 34 gözüne iỉD uygulandı. İşlem öncesi ve sonrası tüm hastalara ön segment renkli fotoğrafı çekildi. Hastalarda görme keskinliği, vaskülarizasyon yaygınlığı ve derinliği işlem öncesi ve sonrasında karşılaştırıldı ve uygulama sayıları, komplikasyonlar kaydedildi.

Bulgular: Vaskülarizasyon nedeni hastaların 12'sinde primeri bilinmeyen lipit keratopati, 9'unda herpes keratiti, 6'sında bakteriyel keratit, 3'ünde korneal grefon reddi, 2'sinde fungal keratit, 2'sinde alkali yanık ve I'inde travma olduğu görüldü. Hastaların I5'inde müdahale edilen tüm damarlar oklüze olurken, 7 hastada bu oran \%75 ve 5'inde \%50 idi. Hastaların I2'sinde ikinci iì, 4'ünde üçüncü iỉD uygulandı. Bazı hastalarda ikinci ve üçüncü işlemlerde başarı artışı olduğu, bazı hastalarda ise istenen yanıtın üçüncü işlemde dahi elde edilemediği tespit edildi.

Sonuç: İnce iğne diatermi ile seçilmiş hastalarda korneal neovaskülarizasyon tedavisinde çok başarılı sonuçlar elde edilmekte, bu yöntem bazı hastalarda ise kısmen yetersiz kalmaktadır.

Anahtar Sözcükler: İnce iğne diatermi; korneal neovaskülarizasyon; oklüzyon. 